\title{
UNE NOUVELLE VOIE D'ABORD DE LA VEINE JUGULAIRE INTERNE
}

\author{
Marcel Boulanger, Eric Delva, Jean-Guy Mailtié et Bernard Paiement
}

TANT EN MILIEU ChiruRgical QUe MÉdical, la surveillance et le traitement des malades graves nécessitent de plus en plus fréquemment la présence d'un cathéter veineux central. L'abord de la veine sous-clavière conserve ses adeptes, mais ses réels dangers parfois dramatiques ont fait que de nombreux centres lui préfèrent maintenant la veine jugulaire interne (VJI).

De nombreuses techniques ont été décrites ${ }^{1-8}$ et toutes les séries montrent un taux d'échecs et de complications très faible. A côté de complications exceptionnelles (pneumo ou hydrothorax, pneumomédiastin, lésion du pneumogastrique ou de la trachée, syndrome de Claude Bernard-Horner) la ponction de la carotide reste le principal écueil du cathétérisme de la veine jugulaire interne. Elle n'occasionne le plus souvent qu'un hématome sans gravité mais des accidents vasculaires cérébraux ont été rapportés.

Si ces incidents techniques sont très rares dans les grands centres qui utilisent quotidiennement la technique de la veine jugulaire interne, ils sont beaucoup plus fréquents pour l'utilisateur inexpérimenté qui n'a recours qu'occasionnellement à une voie veineuse centrale et qui doit alors opérer parfois dans des conditions d'urgence.

Ces raisons nous ont donc fait rechercher une technique fiable, aux repères simples dont le taux de complications ne soit pas lié à l'expérience de l'opérateur.

\section{Anatomie (Figure 1)}

La veine jugulaire interne est un vaisseau de gros calibre (13 à $15 \mathrm{~mm}$ de diamètre) situé juste sous le sternocléidomastoïdien (SCM), plus superficiellement qu'on ne l'imagine communément. La carotide est en dedans et en arrière de celle-ci. La veine jugulaire interne droite est utilisée de préférence à la gauche car le trajet vers l'oreillette droite est plus direct. On a donc supposé qu'un point de pénétration cutanée situé au bord interne du sternocléidomastoïdien donc à l'aplomb de la carotide et un trajet externe rasant la face postérieure de ce muscle, permettraient d'atteindre la veine jugulaire interne tout en se tenant à l'écart de la carotide.

\section{Techinique (Figure 2)}

La malade est en décubitus dorsal, en léger Tredelenbourg. L'opérateur se place à la tête du patient, ou latéralement du côté opposé au point de ponction. La tête

Marcel Boulanger, M.D., Eric Delva, M.D., Jean-Guy Maillé, M.D. et Bernard Paiement, M.D. Département d'Anesthésiologie et Réanimation de l'Institut de Cardiologie de Montréal et Département d'Anesthésiologie de l'Université de Montréal, 5000 est Bélanger, Montréal H1T IC8, Québec, Canada. 


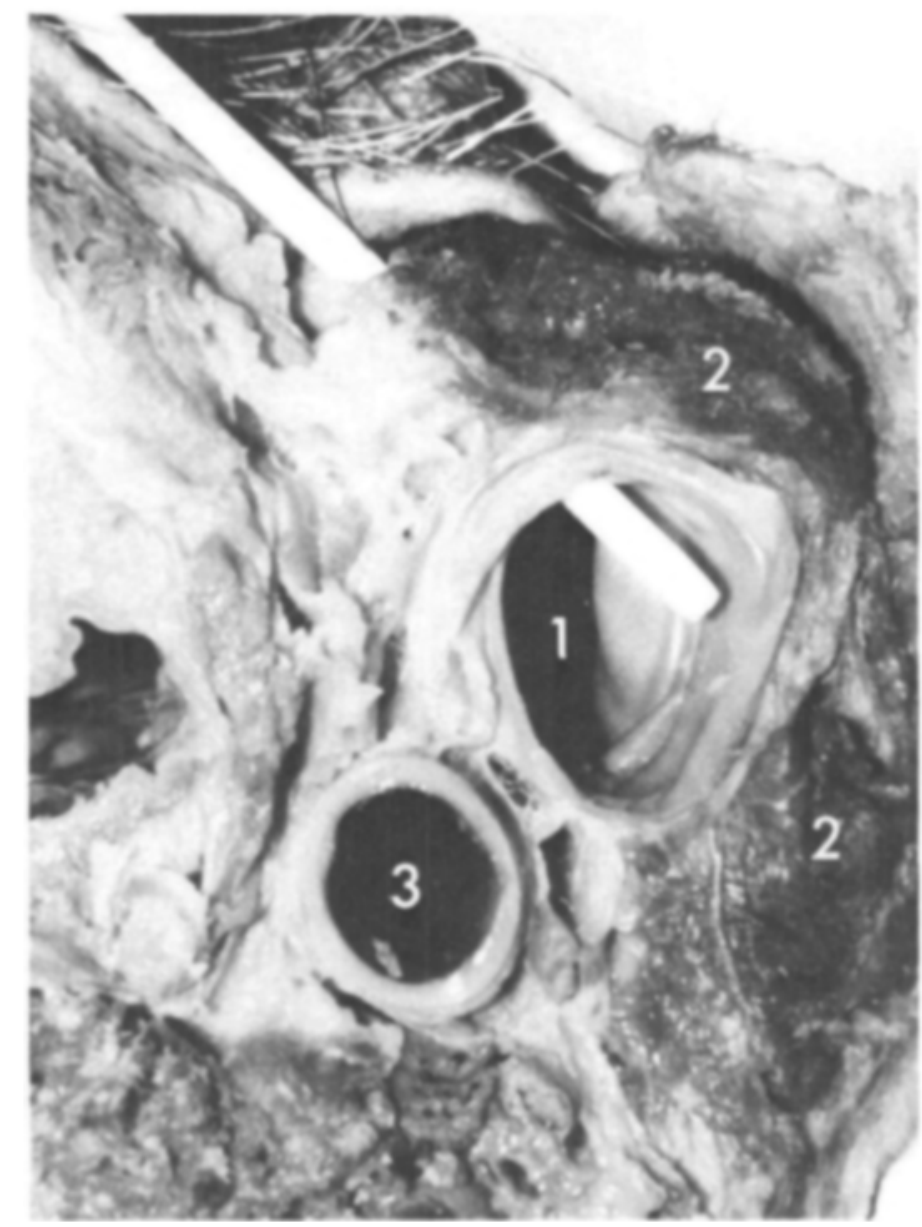

Frgune 1. Coupe transversale de la région cervicale au niveau de $C_{4}$. (1) veine jugulaire interne, (2) sternocleidomastoïdien, (3) carotide. Cette figure montre le trajet externe et superficiel juste sous le SCM. La carotide reste à l'écart de la direction de l'aiguille.

est mise en extension et en rotation forcée du côté opposé. On pince le sternocléidomastoïdien pour apprécier sa masse musculaire.

Le point de repère cutané est situé sur le bord interne du sternocléidomastoüdien à la hauteur du bord supérieur du cartilage thyroïde. (Figure 2a) L'aiguille est dirigée en bas et en dehors en formant un angle d'environ $50^{\circ}$ avec le bord interne du stemocléidomastoidien (en direction de la jonction du tiers interne et du tiers moyen de la clavicule) (Figure 2b). Elle est enfoncée tangentiellement en rasant la face postérieure du muscle.

La progression se fait lentement en maintenant une aspiration constante dans la seringue qui est presque au contact du maxillaire inférieur. Le trajet est superficiel comme si l'aiguille devait ressortir plus bas à quelques centimètres en dehors du bord externe du sternocléiodmastoïdien. Il faut cependant veiller à ne pas pénétrer dans l'épaisseur du muscle.

La veine jugulaire interne est trouvée après un trajet de 2 à $4 \mathrm{~cm}$. Une fois la 


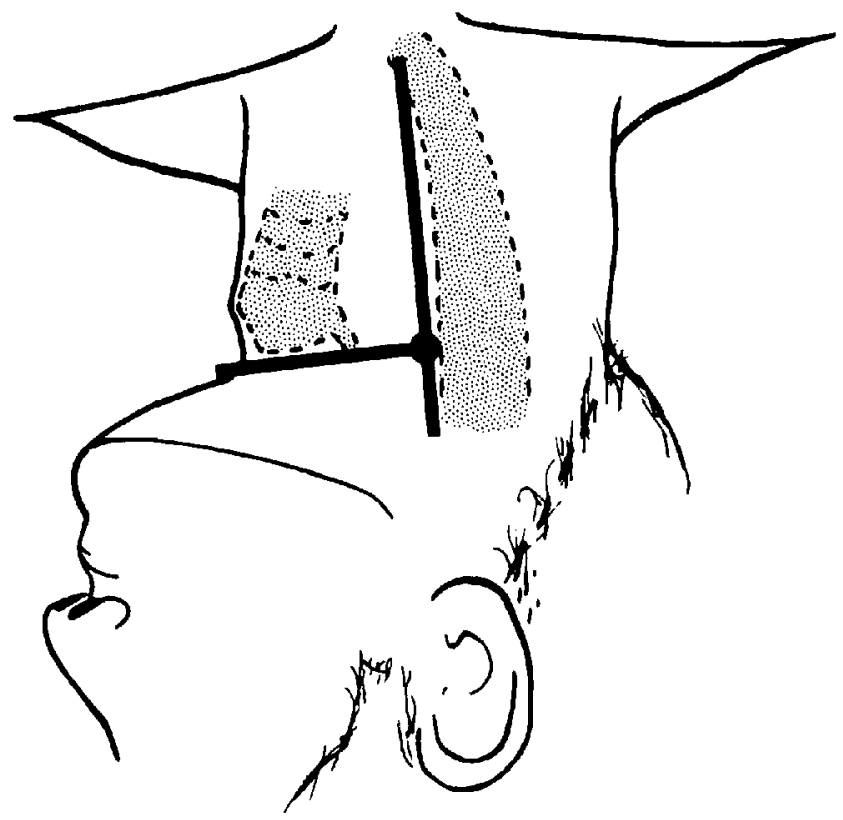

Fıcune 2a. Technique. Le point de repère cutané se situe sur le bord interne du SCM à la hauteur du bord supérieur du cartilage thyroïde.



Figure 2b. Technique. L'aiguille est enfoncée avec un angle d'environ $50^{\circ}$ par rapport au bord interne du SCM. Une fois la veine ponctionnée, l'angle est fermé et l'aiguille est enfoncée dans la lumière de la VJI. 


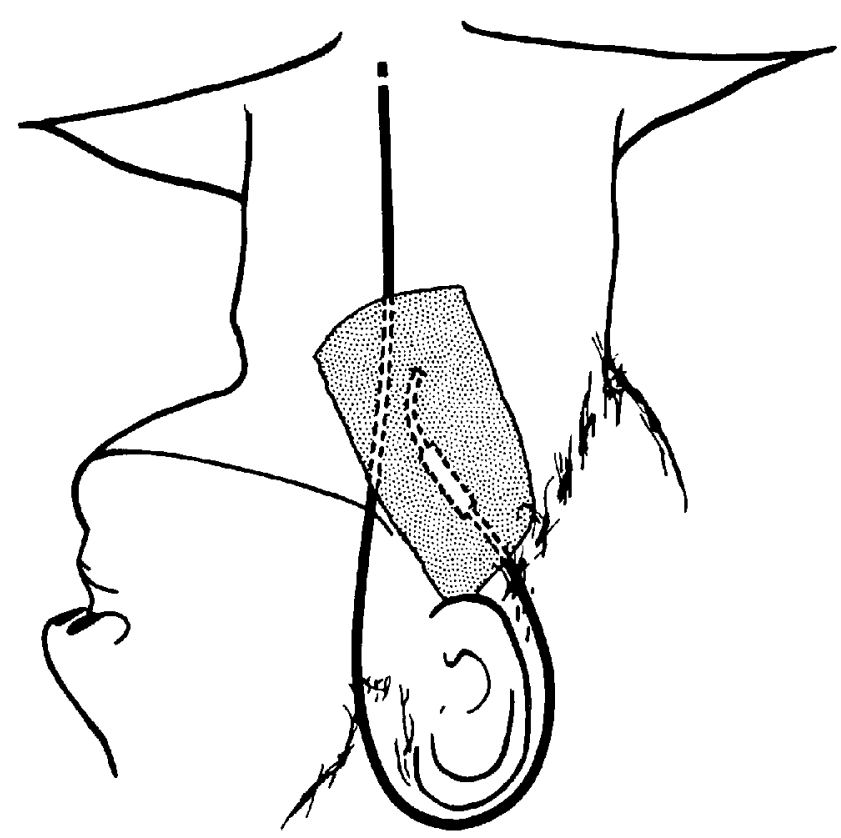

Figure 2c. Technique. La fixation est facile en pratiquant une boucle autour de l'oreille du malade.

veine ponctionnée, l'angle avec le sternocleidomastoïdien est fermé et l'aiguille est amenée dans l'axe du vaisseau et enfoncée de quelques centimètres dans la lumière. Cette façon de procéder permet de cathétériser la veine sans la transfixier malgré l'angle important entre la direction de l'aiguille et l'axe du vaisseau (Figure 3).

Le cathéter ${ }^{*}$ est ensuite engagé et descendu sans difficulté. Le guide est ressorti et la fixation est facile en faisant une boucle autour de l'oreille du patient (Figure 2c).

En cas d'échec, l'aiguille est retirée jusqu'à la peau et enfoncée à nouveau un peu plus profondément et avec un angle plus fermé.

Nous utilisons aussi cette voie pour mettre en place les cathéters de Swan Ganz. Les principaux avantages que nous trouvons à notre abord par rapport aux techniques antérieures (Figure 4 ) sont:

le point de ponction haut situé qui élimine tout risque de pneumothorax, la direction de dedans en dehors de l'aiguille et son trajet superficiel qui rendent la ponction carotidienne exceptionnelle.

Cette méthode est fiable et s'enseigne facilement. A preuve les résultats illustrés au tableau I des 100 premiers cathétérismes de la veine jugulaire interne réalisés par neuf résidents qui n’avaient jamais pratiqué de ponction de cette veine.

Ces chiffres nous apparaissent assez éloquents si l'on se souvient que le taux d'échec et de ponction accidentelle de la carotide est généralement fonction de l'expérience de l'opérateur et que tous ces sujets en étaient à leurs premières armes.

"Sub-clavian/jugular Infuset, Sorenson Research Co., Salt Lake City, Utah 84115. 


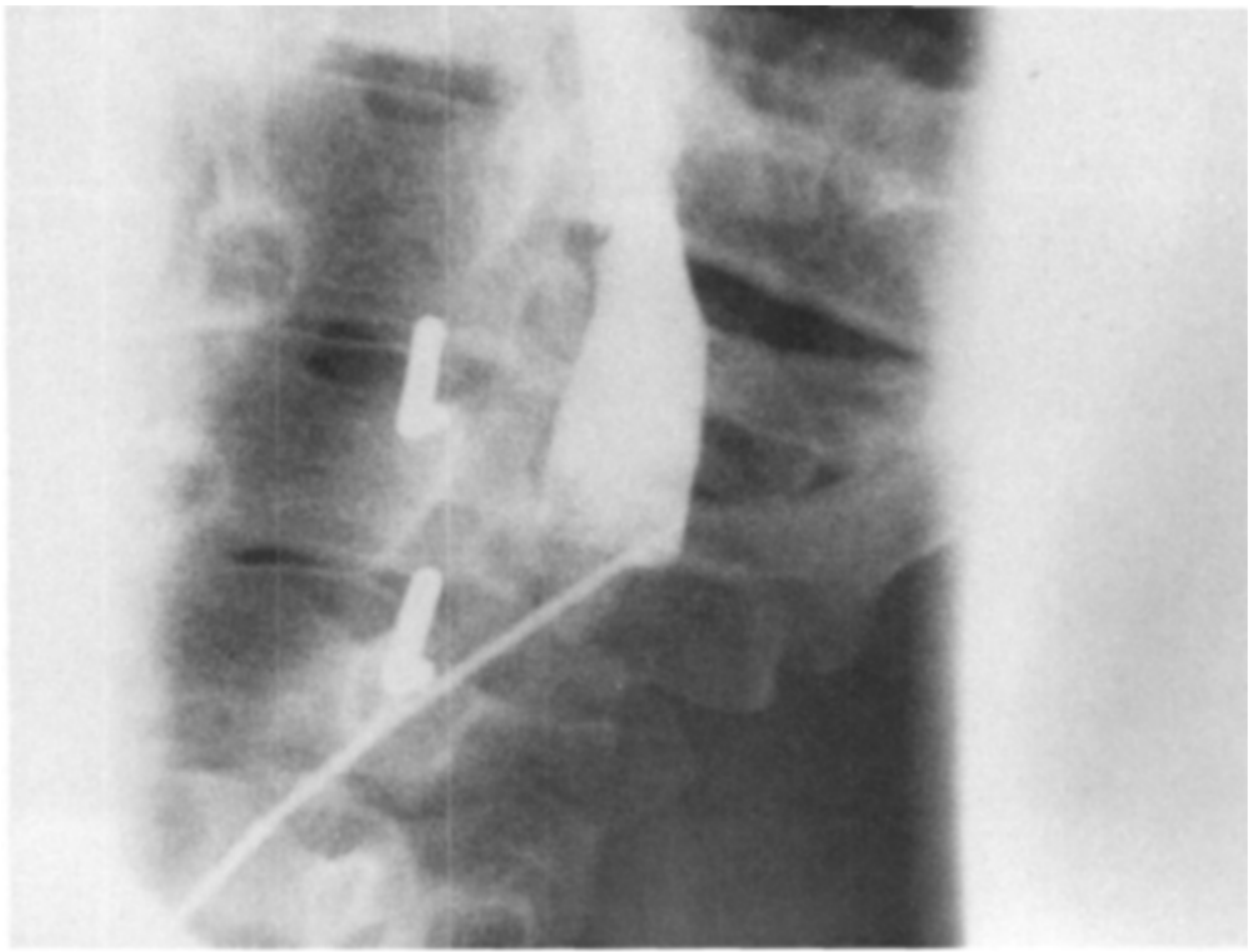

Figure 3. Angiographie. Elle montre le gros calibre de la VJI et l'angle important entre la direction de l'aiguille et l'axe du vaisseau. Les marques de plomb indiquent le bord interne du SCM.

\section{Technique}

With the patient lying on his back in slight Tredelenburg position, the head is hyper-extended and rotated to the opposite side. The cutaneous point of entry is identified (Figure 2a); it lies on the medial border of the sternocleidomastoid muscle at the level of the superior border of the thyroid cartilage. The operator stands on the opposite side from the point of entry. The needle is directed inferiorly and laterally, forming an angle of about $45^{\circ}$ to $50^{\circ}$ with the medial border of the sternocleidomastoid (Figure 2b). It is directed with very little angle with the plane of the skin to remain in close vicinity to the posterior aspect of the muscle. The path is superficial as if the needle would emerge $2 \mathrm{~cm}$ beyond the external border of the sternocleidomastoid muscle. Once the vein is entered, the angle with the sternocleidomastoid muscle is closed, the needle shifted (Figure 2b) in the axis of the vessel and pushed forward in the lumen.

This technique makes it possible to catheterize the vein without passing through, despite the wide angle between the direction of the needle and the axis of the vessel. Indeed, at this level, the internal jugular vein represents its widest diameter.

The catheter is already connected to an intravenous drip and is threaded down without difficulty and taped in place (Figure $2 \mathrm{c}$ ).

This technique differs from previously described techniques by two main points (Figure 4): the high point of entry, which reduces the liability of pneumothorax, 


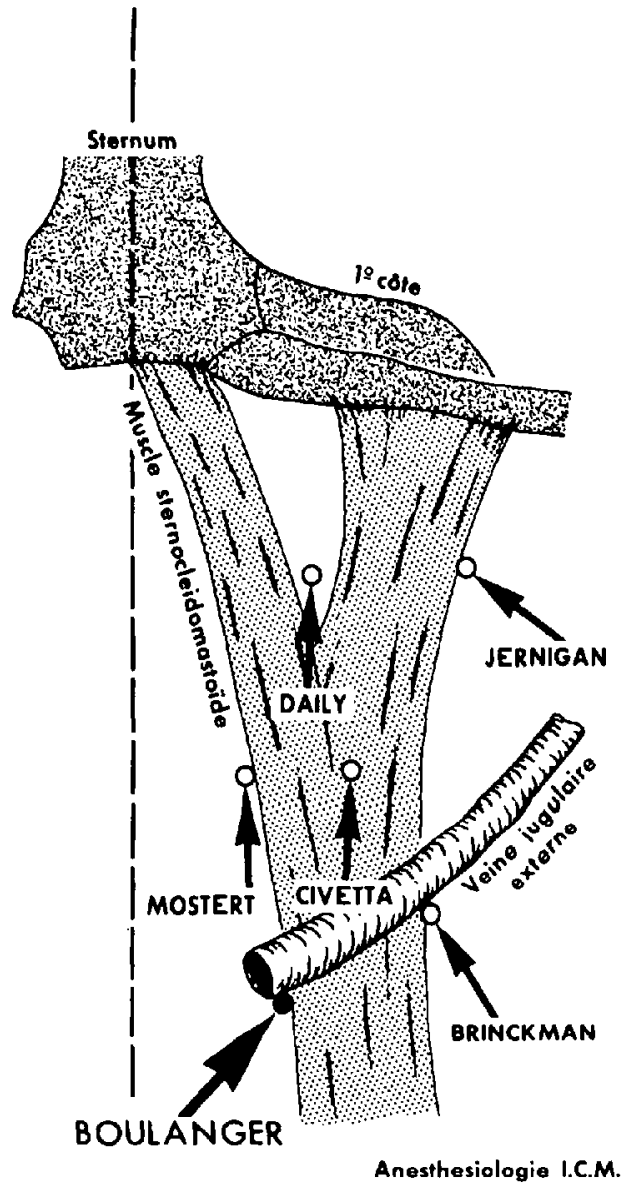

Ficure 4. Repères cutanés et direction de l'aiguille des différentes techniques décrites pour le cathétérisme de la VJI.

TABLEAU I

PONCTION JUGULAIRE INTERNE

TAUX DE SUCces

\begin{tabular}{lcccc}
\hline & & & & \\
& Nombre & Succès & Echec & $\begin{array}{c}\text { Ponction } \\
\text { Carotide }\end{array}$ \\
\hline R1 & 20 & 19 & 1 & 0 \\
R2 & 20 & 18 & 2 & 0 \\
R3 & 20 & 20 & 0 & 0 \\
R4 & 10 & 10 & 0 & 0 \\
R5 & 7 & 6 & 1 & 1 \\
R6 & 3 & 3 & 0 & 0 \\
R7 & 8 & 7 & 1 & 0 \\
R8 & 2 & 1 & 1 & 1 \\
R9 & 10 & 10 & 0 & 2 \\
Total: & 100 & 94 & 6 & \\
\hline
\end{tabular}


and the outward and superficial path of the needle, which makes accidental puncture of the carotid artery most unusual.

This method is easy to teach and dexterity is easy to acquire.

Table I shows our experience with nine inexperienced residents who achieved a 94 per cent success rate in a total of 100 canulations, with only two carotid punctures.

\section{RÉSUMÉ}

Une nouvelle technique de cathétérisme de la veine jugulaire interne est décrite. Le trajet de l'aiguille superficiel, de dedans en dehors à partir d'un point de pénétration cutanée haut situé permet de ponctionner la veine jugulaire interne tout en se maintenant à l'écart de la carotide. Cette technique est utilisée avec succès et en toute sécurité dès les premières tentatives.

Nous remercions le docteur Aloïs Pospisil du département d'Anatomie de la Faculté de Médecine de l'Université de Montréal de son aimable collaboration.

\section{SUMMARY}

This paper describes a new technique for the canulation of the internal jugular vein. A transsection of the neck at the level of $\mathrm{C} 4$ (upper border of the thyroid cartilage) (Figure 1) shows the relative position of the internal jugular vein, the carotid artery and the sternocleidomastoid muscle.

The internal jugular vein at this level is more superficial than is usually imagined. A cutaneous point of entry placed at the level of the thyroid cartilage on the medial border of the sternocleidomastoid muscle would be directly above, at the zenith of the carotid artery. From that point, moving a needle externally hugging the posterior aspect of the muscle will make it possible to reach the vein while actually moving away from the carotid artery.

\section{BIBLIOGRAPHIE}

1. Bhinkman, A.J., Costley, D.D. Intemal jugular venipuncture. J.A.M.A. 223: 182-183 (1973).

2. Civetta, J.M., Gabel, J.C., \& Gemer, M. Internal jugular-vein puncture with a margin of safety. Anesthesiology 36: 622-623 (1972).

3. Clot-Paimboeuf, $C$. Cathétérisme percutané de la veine jugulaire interne. Presse Méd. 79: 819-820 (1971).

4. Daily, P.O., Griepp, R.B., \& Saumway, N.E. Percutaneous internal jugular vein cannulation. Arch. Surg. 101: 534-536 (1970).

5. Defalque, R.J. Percutaneous catheterization of the internal jugular vein. Anesth. Analg. 53: 116-121 (1974).

6. Estanove, S. \& Cieorge, M. La voie jugulaire interne percutanée. Ann. Anesth. Franç. XIV, 305-311 (1973).

7. Jemngan, W.R., Gardner, W.C., Mahr, M.M., \& Milburn, J.L. Use of the intemal jugular vein for placement of central venous catheter. Surg. Gynec. Obstet. 130: 520$524(1970)$.

8. Mostert, J.W., Gerald, M.K., \& Murphy, G.P. Safe placement of central venous catheter into internal jugular veins. Arch. Surg. 101: 431-432 (1970). 